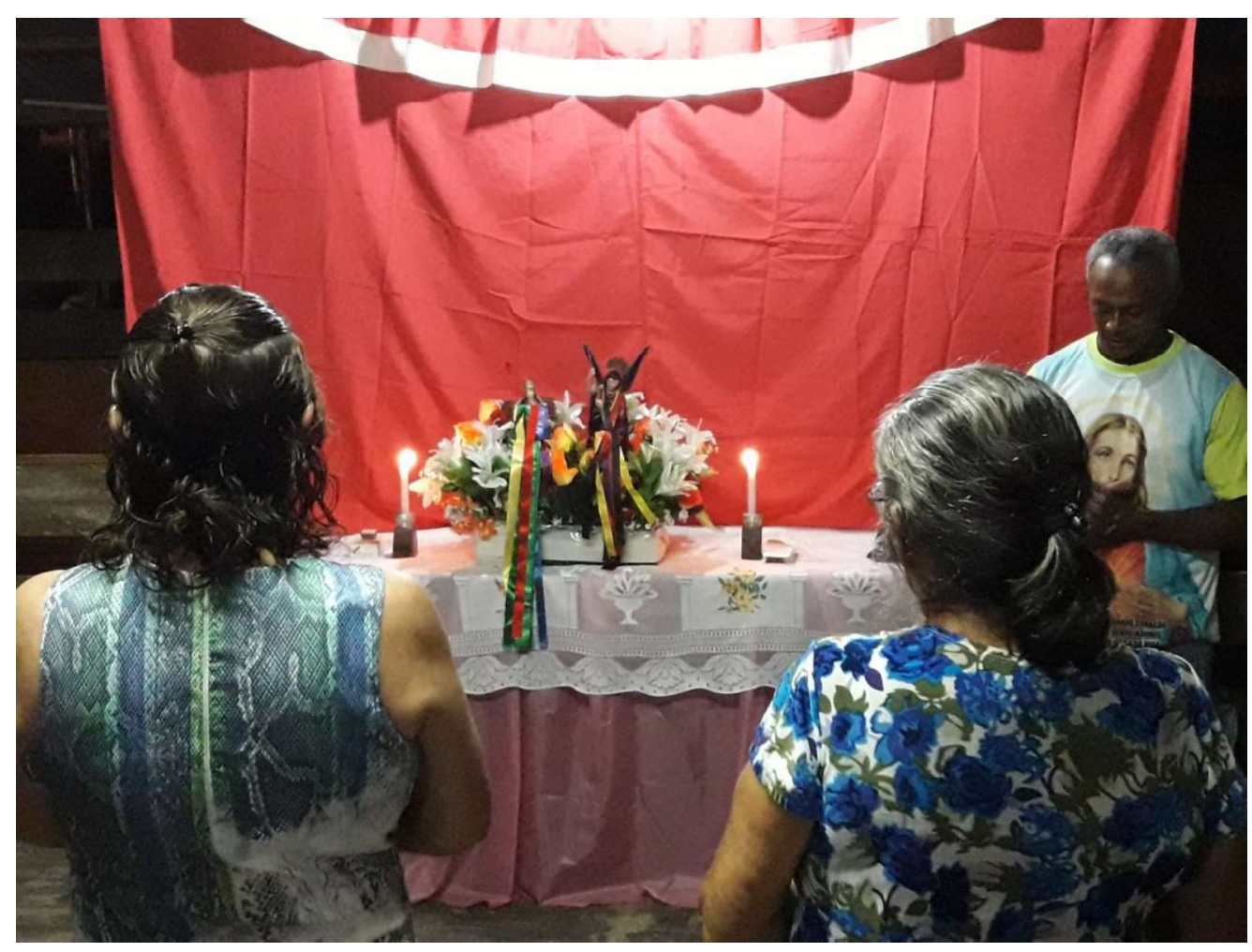

\title{
MEMÓRIAS, TRADIÇÃO E DEVOÇÃO: LADAINHA EM LOUVOR A SÃO MIGUEL DA COMUNIDADE TAUERÁ DE BEJA
}

\section{MEMORIES, TRADITION AND DEVOTION: LADAINHA IN LOUVOR THE SÃO MIGUEL OF THE COMMUNITY TAUERÁ DE BEJA}

Samuel Antonio Silva do Rosario ${ }^{1}$ Jocenilda Pires de Sousa do Rosario ${ }^{2}$

Sinopse: Este vídeo apresenta um recorte de uma prática cultural e religiosa de quase 100 anos, presente em uma comunidade da zona rural do município de Abaetetuba, Pará, Brasil. Durante o terceiro sábado do mês de julho é realizada na comunidade do ramal Tauerá de Beja uma procissão em homenagem a São Miguel, onde a comunidade vivencia momentos dedicados a essa divindade. Uma característica marcante e bem peculiar desse momento é a prática de cantar ladainhas de maneira tradicional com vozes bem divididas e se utilizando de palavras em latim vulgar, algo que se mantém há gerações e que acabou se tornando uma das essências dessa tradição religiosa, misturando memórias e devoção. Na captura das imagens foi usada uma máquina Nikon Coolpix P520.

Palavras-chave: Tradição, Memória, Ladainha, Cotidiano.

\footnotetext{
${ }^{1}$ Professor do Instituto Federal de Educação, Ciência e Tecnologia do Pará (IFPA). Mestre em Linguagens e Saberes na Amazônia (UFPA). Membro do Grupo de Pesquisa LELIM - Laboratório de Estudos Linguagem, Imagem e Memórias (UFPA), e-mail: samuel.rosario@ifpa.edu.br

${ }^{2}$ Doutoranda em Estudos Literários (UFPA). Mestra em Linguagens e Saberes na Amazônia (UFPA). Membro do Grupo de Pesquisa LELIM - Laboratório de Estudos Linguagem, Imagem e Memórias (UFPA), e-mail: joufpa16@gmail.com
} 
Synopsis: This video presents a cut of a cultural and religious practice of almost 100 years, present in a community of the rural zone of the municipality of Abaetetuba, Pará, Brazil. During the third Saturday of the month of July a procession is held in the Tauerá community of Beja in honor of St. Michael, where the community experiences moments dedicated to this divinity. A striking and peculiar characteristic of this moment is the practice of singing ladainhas in a traditional way with well-divided voices and using words in ordinary Latin, something that has been going on for generations and that has become one of the essence of this religious tradition, mixing memories and devotion. A Nikon Coolpix P520 camera was used to capture the images.

Keywords: Tradition, Memory, Litany, Everyday Life.

\section{FICHA TÉCNICA:}

Produção: Samuel A S do Rosario e Jocenilda P S do Rosario

Imagens/Operador de Câmera: Samuel A S do Rosario e Jocenilda P S do Rosario

Edição: Samuel A S do Rosario

Roteirista/Texto: Samuel A S do Rosario e Jocenilda P S do Rosario

\section{CREDITS:}

Production: Samuel A S do Rosario e Jocenilda P S do Rosario

Images/Cameraperson: Samuel A S do Rosario e Jocenilda P S do Rosario

Edition: Samuel A S do Rosario

Scriptwriter/Text: Samuel A S do Rosario e Jocenilda P S do Rosario

Recebido em 10.04.2019

Aprovado em 14.04.2019 